\title{
Microencapsulation Stability of Stevia Leaf Extracts of Stevia rebaudiana Bert Using Inulin-Chitosan
}

\author{
Mutmainah1 $^{1 *}$, Yohanes Martono², Yuvianti Dwi Franyoto'1, Lia Kusmita1 \\ ${ }^{1}$ STIFAR "Yayasan Pharmasi Semarang”, Letjend Sarwo Edhie Wibowo KM 1, Semarang, Indonesia \\ ${ }^{2}$ Chemistry Department, Faculty of Science and Mathematics, Universitas Kristen Satya Wacana, Salatiga, Indonesia \\ Email: *mutmainah.stifar@gmail.com
}

How to cite this paper: Mutmainah, Martono, Y., Franyoto, Y.D. and Kusmita, L. (2019) Microencapsulation Stability of Stevia Leaf Extracts of Stevia rebaudiana Bert Using Inulin-Chitosan. Open Access Library Journal, 6: e5925.

https://doi.org/10.4236/oalib.1105925

Received: November 15, 2019

Accepted: November 30, 2019

Published: December 3, 2019

Copyright $\odot 2019$ by author(s) and Open Access Library Inc.

This work is licensed under the Creative Commons Attribution International License (CC BY 4.0).

http://creativecommons.org/licenses/by/4.0/

\begin{abstract}
Extract of Stevia leaf of rebaudiana Bert has a content that is easily oxidized by the presence of light and heating so it is not stable during storage. A microencapsulation process is carried out which aims to protect the contents in the extract. This study aims to determine the effect of storage temperature on the physical stability of the microencapsulation of Stevia leaf of rebaudiana Bert with a combination of encapsulants inulin chitosan. A study was conducted to determine the effect of temperature on the microencapsulation stability of Stevia leaf of rebaudiana Bert over a period of 1 month. Tests carried out on the microencapsulation of Stevia leaf of rebaudiana Bert include the examination of the physical parameters of the microcapsules, namely the microencapsulation yield, moisture content, solubility, flow rate, non-encapsulated and encapsulated extracts content and determination of particle distribution and morphological form. The test results show that the storage temperature does not affect the microencapsulation stability of Stevia leaf of rebaudiana Bert, because the SEM test results did not change i.e. the particle size distribution of $1-1000 \mu \mathrm{m}$. The average yield obtained from making microencapsulation of Stevia leaf extract of rebaudiana Bert was $98.20 \%$. Storage temperatures of $5^{\circ} \mathrm{C}, 25^{\circ} \mathrm{C}$ and $40^{\circ} \mathrm{C}$ affect the physical stability of the microencapsulation of Stevia leaf extract of rebaudiana Bert due to changes in the profile of physical characteristics during storage.
\end{abstract}

\section{Subject Areas}

Nutrition

\section{Keywords}

Stevia Leaf Extract, Microencapsulation, Physical Stability, Inulin, Chitosan 


\section{Introduction}

Stevia leaf contains several sweetening compounds such as steviosida, rebaudiosida A, B, C, D, E and dulcoside A and B. Steviosida has no teratogenic effect [1], mutagenic [2], and carcinogenic [3]. Stevia leaf (Stevia rebaudiana Bertoni) contains various substances such as alkaloids, tannins and flavonoids [4]. Flavonoids are very easily oxidized by light, air and heating so they are unstable when storing [5]. Encapsulation techniques are needed to protect the antioxidant activity in Stevia leaf of rebaudiana Bert [6].

This study aims to determine the effect of temperature $\left(5^{\circ} \mathrm{C}, 25^{\circ} \mathrm{C}, 40^{\circ} \mathrm{C}\right)$ on the microencapsulation stability of Stevia leaf of rebaudiana Bert conducted over a period of 1 month with physical characteristics as parameters tested. The temperature selection represents the storage conditions of cold temperature, room temperature and hot temperature. Storage conditions in the refrigerator range between temperature $5^{\circ} \mathrm{C} \pm 3^{\circ} \mathrm{C}$ [7]. The temperature of $40^{\circ} \mathrm{C}$ is chosen based on the drug stability test guidelines i.e. an accelerated stability test is carried out at temperature $40^{\circ} \mathrm{C} \pm 2{ }^{\circ} \mathrm{C}$. The temperature of $25^{\circ} \mathrm{C}$ used at room temperature usually ranges between $20^{\circ} \mathrm{C}-25^{\circ} \mathrm{C}$ [8].

The choice of encapsulation is also very influential on the success of nanoencapsulation. Carbohydrates are widely used in encapsulation, but research on inulin as encapsulation is still limited. The use of inulin as encapsulant in nanoencapsulation also has limitations such as large particle size, besides that inulin also has a sticky character and hygroscopic thus limiting their use as encapsulants. To produce nanoscale particle size in the encapsulation of stevia leaf extract, the presence of inulin can be partially replaced by chitosan. Chitosan is a natural polymer that can be linked by crosslink when a crosslinked agent is added (Sarah, 2001).

\section{Materials and Methods}

\subsection{Tools and Materials Used}

The tools used are spray dryer (Buchi Mini Spray Dryer B-29-), rotary vacuum evaporator (Buchi R-114), Scanning Electron Microscope (JEOL JSM-5310LV-20 $\mathrm{kV}$ ), analytical balance, homogenizer (Ultra Turrax ${ }^{\circledR} \mathrm{T} 50 \mathrm{Basic}$ ), and glassware. The materials used in this study consisted of stevia leaves obtained from Solo. Inulin, chitosan, $1 \%$ acetic acid, Tween 80 1\%.

\subsection{Microencapsulation of Stevia Leaf Extract}

The microencapsulation of Stevia leaf extract made an emulsion system with the ratio of inulin encapsulation: chitosan is $25: 75 \mathrm{~b} / \mathrm{b}$. Chitosan is dissolved in $1 \%$ acetic acid and then Tween $801 \%$ emulsifiers are added. Furthermore, inulin is put into chitosan solution and homogenized using Homogenizer Ultra Turrax ${ }^{\circledR}$ T50 Basic with a speed of $5000 \mathrm{rpm}$ for 5 minutes. Furthermore, the microencapsulation process of stevia leaf extract is carried out using the spray drying method at a feed rate of $15 \mathrm{ml} /$ minutes and inlet temperature $120^{\circ} \mathrm{C}$. The result- 
ing powder is a microcapsule whose properties are analyzed. Microencapsulation preparations that have been made are then divided into 3 , then stored at temperature of $5^{\circ} \mathrm{C}, 25^{\circ} \mathrm{C}$ and $40^{\circ} \mathrm{C}$. Next, the physical parameters of the microcapsules were analyzed, namely the microencapsulation yield, the moisture content, solubility, flow velocity, the level of the non-encapsulated and encapsulated extracts and the determination of particle distribution and morphological form.

\subsection{Microencapsulation Yield}

Microencapsulation yield was evaluated by comparing the weight of the material after processing it with the material before processed [9].

\subsection{Moist Content}

Microparticles are measured using a moisture meter (moisture balance) at temperature of $105^{\circ} \mathrm{C}$. Then the moisture content of the constant is calculated [10].

\subsection{Solubility Test}

Solubility is evaluated by dissolving 1 gram of sample in $25 \mathrm{ml}$ distilled water and then filtered, filtered paper to obtain residual weight, the results obtained are then calculated against the sample weight to determine the percent of sample that can be dissolved [11].

\subsection{Flow Speed}

Flow speedy is evaluated by inserting a few samples in the flow funnel and then determining the time required for the entire sample to flow [12].

\subsection{Unencapsulated Extract Levels}

Determined by 1 gram of sample was immersed in $20 \mathrm{ml}$ of ethanol, then filtered and the filtrate was measured using a spectrophotometer.

\subsection{Determination of Particle Distribution and Morphological Shape}

Determination of the size distribution of microparticles is done using a light microscope and Scanning Electron Microscope (SEM) [13]. Observation using SEM was done by coating the microcapsules with gold and seen at magnification 5000 times (Table 1).

\section{Results and Discussion}

The average yield obtained from making microencapsulation of Stevia leaf extract of rebaudiana Bert is $98.20 \%$. The yield obtained is quite high, possibly due to the process temperature of low freeze dry so that there is no sublimated material other than water. From the SEM analysis results in Figure 1, it can be seen that the microencapsulation of the Stevia leaf extract of rebaudiana Bert is spherical, uneven, non-porous and micro-sized. Generally the size of a microcapsule product ranges $1-1000 \mu \mathrm{m}$ [14]. 
Table 1. Microencapsules formula of Stevia extract.

\begin{tabular}{cc}
\hline Materials & F1 \\
\hline Stevia leaf extract(ml) & 100 \\
Inulin $(\mathrm{g})$ & 2.075 \\
Chitosan $(\mathrm{g})$ & 6.225 \\
Acetic acid $1 \%(\mathrm{ml})$ & 8.3 \\
Tween $801 \%(\mathrm{ml})$ & 8.3 \\
\hline
\end{tabular}

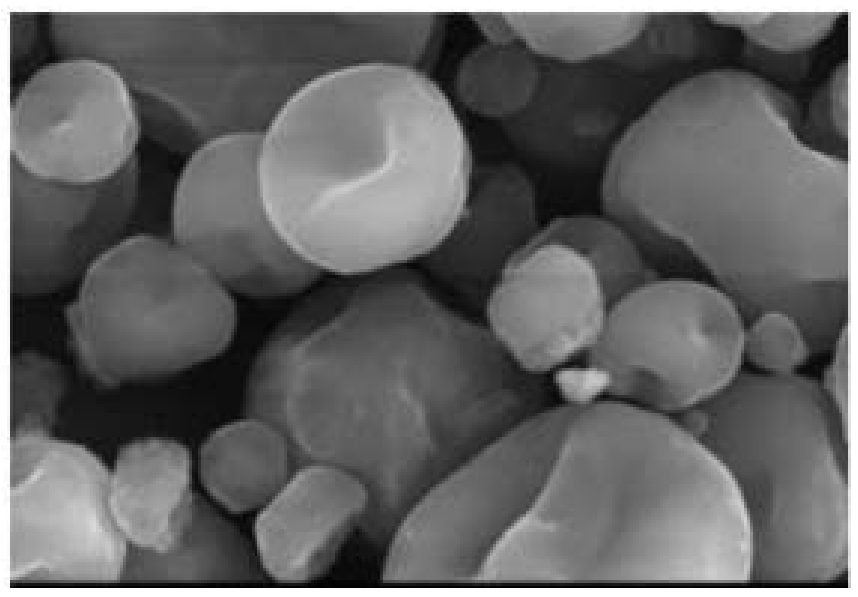

Figure 1. The morphological form of microcapsules of Stevia leaf extract at 5000 times magnification.

The results of microencapsulation physical stability test of Stevia leaf extract of rebaudiana Bert can be seen in Table 2. Storage at temperature of $5^{\circ} \mathrm{C}, 25^{\circ} \mathrm{C}$ and $40^{\circ} \mathrm{C}$ cause the moist content of microencapsulation of Stevia leaf extract of rebaudiana Bert to decrease. This can be caused by the water content in the preparation evaporating and causing the preparation to become dry [15]. Testing the flow rate of microencapsulation of Stevia leaf extract of rebaudiana Bert. Storage at $5^{\circ} \mathrm{C}, 25^{\circ} \mathrm{C}$ and $40^{\circ} \mathrm{C}$ shows that the flow rate of microencapsulation of Stevia leaf extract of rebaudiana Bert is increasing, this is due to a decrease in moisture content. Flow character is affected by humidity, the higher the humidity, the flow characteristics will be worse because the cohesiveness (bonding between particles) is getting stronger so that the microencapsulation ability of Stevia leaf extract rebaudiana Bert to flow becomes more difficult.

Unencapsulated extracts are more susceptible to oxidation and thus reduce the quality of microencapsules [16]. Storage over at temperature of $5^{\circ} \mathrm{C}, 25^{\circ} \mathrm{C}$ and $40^{\circ} \mathrm{C}$ causes the extract encapsulated levels in the microencapsulated preparations of Stevia leaf extract of rebaudiana Bert to decrease. Storage at this temperature causes the solubility of microencapsulation of Stevia leaf extract of rebaudiana Bert to decrease, this can be due to the influence of the moist content will affect the weighing of the sample and show the results more easily dissolved (Figure 2). 
Table 2. The solubility of Stevia extract of Microencapsule.

\begin{tabular}{cc}
\hline Treatment. & Solubility (\%) \\
\hline 1 & $97.96 \pm 0.01$ \\
2 & $97.94 \pm 0.01$ \\
4 & $97.96 \pm 0.11$ \\
5 & $97.95 \pm 0.01$ \\
6 & $97.96 \pm 0.20$ \\
7 & $97.96 \pm 0.01$ \\
8 & $97.93 \pm 0.01$ \\
9 & $97.96 \pm 0.01$ \\
10 & $97.92 \pm 0.02$ \\
11 & $97.96 \pm 0.01$ \\
12 & $97.94 \pm 0.01$ \\
13 & $97.96 \pm 0.02$ \\
\hline
\end{tabular}

Information: Treatment 1: 0 week storage; Treatment $2: 1$ week storage at a temperature of $5^{\circ} \mathrm{C}$; Treatment 3: 1 week storage at a temperature of $25^{\circ} \mathrm{C}$; Treatment $4: 1$ week storage at a temperature of $40^{\circ} \mathrm{C}$; Treatment 5: 2 week storage at a temperature of $5^{\circ} \mathrm{C}$; Treatment 6: 2 week storage at a temperature of $25^{\circ} \mathrm{C}$; Treatment 7:2 week storage at a temperature of $40^{\circ} \mathrm{C}$; Treatment $8: 3$ week storage at a temperature of $5^{\circ} \mathrm{C}$; Treatment 9: 3 week storage at a temperature of $25^{\circ} \mathrm{C}$; Treatment 10:3 week storage at a temperature of $40^{\circ} \mathrm{C}$; Treatment $11: 4$ week storage at a temperature of $5^{\circ} \mathrm{C}$; Treatment 12: 4 week storage at a temperature of $25^{\circ} \mathrm{C}$; Treatment 12: 4 week storage at a temperature of $40^{\circ} \mathrm{C}$.

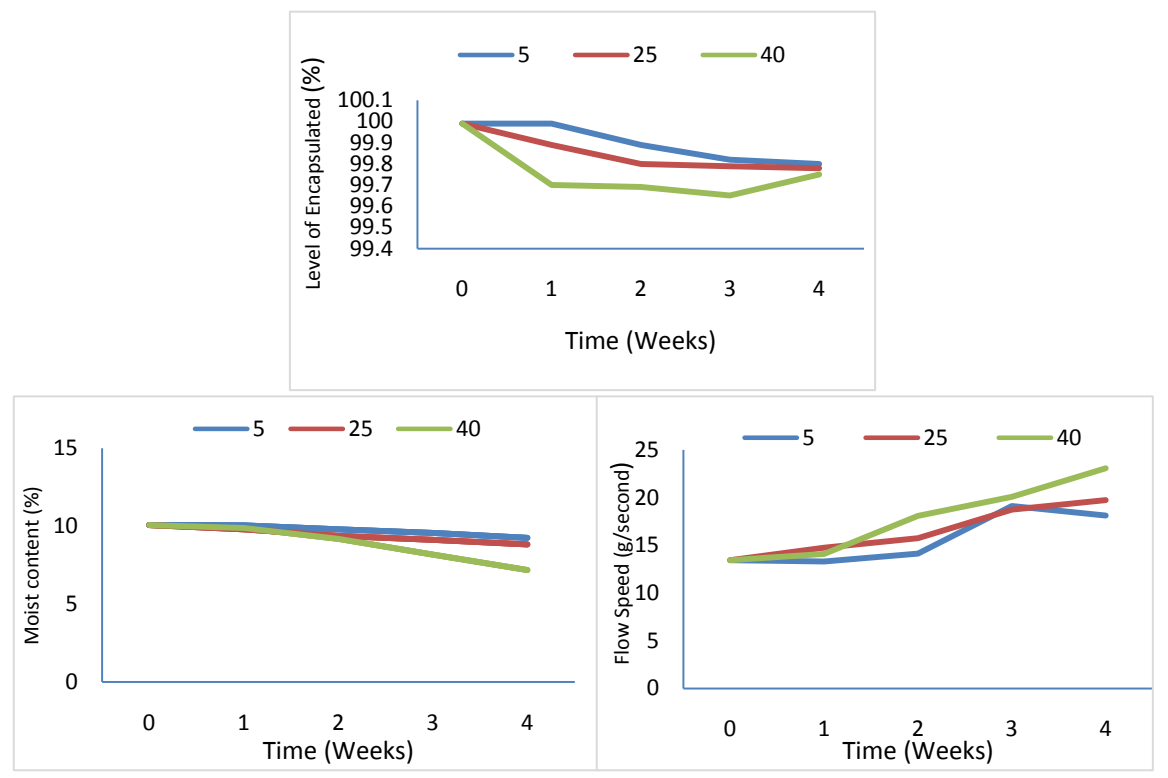

Figure 2. The physical characteristic results of Stevia extract of Microencapsule.

\section{Conclusion}

Storage temperatures of $5^{\circ} \mathrm{C}, 25^{\circ} \mathrm{C}$ and $40^{\circ} \mathrm{C}$ affect the physical stability of the microencapsulation of Stevia rebaudiana Bert leaf extract. 


\section{Acknowledgements}

The Ministry of Research, Technology, and Higher Education for the SKIM Inter-College Research Grant Number DIPA-228/SP2H/LT/DPRM/2019.

\section{Conflicts of Interest}

The authors declare no conflict of interests.

\section{References}

[1] Yodyinguard, V. and dan Bunyawong, S. (1991) Effect of Stevioside on Growth and Reproduction. Human Reproduction, 6, 158K-165K. https://doi.org/10.1093/oxfordjournals.humrep.a137251

[2] Suttajit, M., Vinitketkaumnuem, U., Meevatee, U. and dan Buddhasukh, D. (1993) Mutagenicity and Human Chromosomal Effect of Stevioside. A Sweetener from Steviarebaudiana Bertoni. Environmental Health Perspective, 101, 53-56. https://doi.org/10.1289/ehp.93101s353

[3] Xili, L., Chengjiany, B., Eryi, X., Reiming, S., Yuenming, W., Haodong, S. and Hiyian, H. (1992) Chronic Oral Toxicity and Cardnogenicity Study of Stevioside in Rats. Food and Chemical Toxicology, 30, 957-965. https://doi.org/10.1016/0278-6915(92)90181-J

[4] Kaushik, R., Pradeep, N., Vamshi, V., Geetha, M. and Usha, A. (2010) Nutrient Composition of Cultivated Stevia Leaves and the Influence of Polyphenols and Plant Pigments on Sensory and Antioxidant Properties of Leaf Extracts. Journal of Food Science and Technology, 47, 27-33. https://doi.org/10.1007/s13197-010-0011-7

[5] Zielinski, H., Mishalska, A., Amigo-Benavent, M., Del Castillo, M.D. and dan Piskula, M.K. (2009) Changes in Protein Quality and Antioxidant Properties of Buckwheat Seeds and Groats Induced by roasting. Journal of Agricultural and Food Chemistry, 57, 4771-4777. https://doi.org/10.1021/jf900313e

[6] Munin, A. and dan Florence, E. (2011) Encapsulation of Natural Polyphenolic Compounds; A Review. Pharmaceutics, 3, 793-829.

https://doi.org/10.3390/pharmaceutics3040793

[7] International Conference of Harmonization (2003) Food and Drug Administration. Guidance for Industry Q1A (R2) Stability Testing of New Drug Substances and Products. Department of Health and Human Services.

[8] Gennaro, A.R. (2000) Remington: The Science and Practice of Pharmacy. 20th Edition, Mack Publishing Company Pennsylvania, Pennsylvania, PA.

[9] Ahn, J.H., Kim, Y.P., Seo, E.M., Choi, Y.K. and dan Kim, H.S. (2007) Antioxidant Effect of Natural Plant Extracts on The Microencapsulated High Oleic Sunflower Oil. Journal of Food Engine, 84, 327-334. https://doi.org/10.1016/j.jfoodeng.2007.05.029

[10] Kasih, N. (2014) Formulasidan Karakterisasi Mikropartikel Ekstrak Etanol 50\% Kulit Buah Manggis (Garcinia mangostana L.) dengan Metode Semprot Kering (Spray Drying) Skripsi. Fakultas Kedokterandan Ilmu Kesehatan Program StudiFarmasi UIN Syarif Hidayatullah Jakarta, Jakarta.

[11] Nasrullah, F. (2010) Pengaruh Komposisi Bahan Pengkapsul Terhadap Kualitas Mikrokapsul Oleoresin Lada Hitam (Piper nigrum L.) Skripsi. Departemen Ilmu dan Teknologi Pangan, Institut Pertanian Bogor, Bogor.

[12] Gowda, D.V., Khan, M.S., Venkatesh, M.P., Sowjaya, A.S. and Shivakumar, H.G. 
(2010) Preparation and Evaluation of HPMC and Eudragit Microparticle Loaded with Diltiazem Hidrokloridauntuk Penghantaran Terkontrol. Scholar Research Library.

[13] Staniforth, J. (2002) Powder Flow. In: Aulton, M.E., Ed., Pharmaceutic. The Science of Dosage Form Design, Edisi II, Churchill Livingstone, Edinburg, London, New York.

[14] Obeidat (2009) Microencapsulation: Convenient Mode of Drug Delivery in Novel Drug Delivery System. International Journal of Pharmacy and Life Sciences, 3, 1555-1562.

[15] Siregar, C.J.P. and dan Wikarsa, S. (2010) Teknologi Farmasi Sediaan Tablet Dasar-Dasar Praktis. Buku Kedokteran EGC, Jakarta.

[16] Shahidi, F. and dan Han, X.Q. (2009) Encapsulation of Food Ingredients. Critical Review in Food Science and Nutrition, 33, 501-547.

https://doi.org/10.1080/10408399309527645 